\title{
Jurassic maximum flooding surfaces in the Greater Caucasus Basin (Northern Neo-Tethys)
}

\author{
Dmitry A. Ruban \\ Department of Geology, University of Pretoria, \\ Pretoria, South Africa
}

\begin{abstract}
The Greater Caucasus evolved in the Jurassic as a large elongated back-arc basin on the northern periphery of the Neo-Tethys Ocean. The semi-quantitative analysis of proportions between marine and continental facies for each of 67 time slices produced a detailed curve depicting transgressive and regressive episodes. Five remarkable peaks on this curve are interpreted as the maximum flooding surfaces (MFSs). They are established at the Sinemurian/Pliensbachian boundary (MFS1), in the upper Pliensbachian (MFS2), the lower Aalenian (MFS3), the upper Bajocian (MFS4) and the lower Tithonian (MFS5). All surfaces except for MFS4 occur within typical MFS-marking layers. The Jurassic MFSs of the Greater Caucasus Basin do not match transgression peaks of the 1st-order cycles of Western Europe and the MFSs of Arabia. Their correspondence to the global eustatic peaks also remains uncertain. The most unexpected event is found in MFS3, which occurs at a time of prominent global sea-level fall. Errors in constraints and interpretations as well as influences of regional tectonic activity explain a specificity of the regional MFSs. The use of the regional Jurassic MFSs from the Greater Caucasus Basin for correlation purposes, therefore, appears doubtful.
\end{abstract}

Key words: maximum flooding surface, transgression, eustasy, sequence stratigraphy, correlation, Greater Caucasus Basin, Jurassic

\section{Introduction}

Establishing key surfaces is an important procedure in sequence stratigraphic modeling of any given sedimentary basin. The maximum flooding surface (MFS) is one of the most important surfaces. It corresponds to the peak of landward migration of the shoreline, creating a boundary between the transgressive

Address: D. A. Ruban: P.O. Box 7333, Rostov-na-Donu, 344056, Russia, e-mail: ruban-d@mail.ru, ruban-d@rambler.ru

Received: May 20, 2008; accepted September 10, 2008 
systems tract and the highstand systems tract (Van Wagoner et al. 1988; Galloway 1989; Bhattacharya 1993; Posamentier and Allen 1999; Catuneanu 2006; Veeken 2007). Care should be taken when linking transgression peaks to the deepening episodes, because shoreline trajectories and changes in basin depth are different patterns, whose direct relationships are misty in some cases (Catuneanu 2006; Ruban 2007a). The MFSs are generally conformities (with some exceptions) with a low degree of diachroneity and a high preservation potential (Galloway 1989; Catuneanu 2006). This makes them important for interregional correlations and verification of the global eustatic curves.

Jurassic MFSs are justified in large regions such as Western Europe (Jacquin and de Graciansky 1998) and Arabia (Sharland et al. 2001; Al-Husseini 2007; Simmons et al. 2007; Al-Husseini and Matthews 2008). However, data from any region in between would help to improve the correlations. Obviously the Caucasus, where large elongated basins evolved since the Early Jurassic (Fig. 1), can serve this purpose. A compilation of knowledge on the Jurassic sedimentary complexes, facies analysis, and a reconstruction of transgressive-regressive cycles for this region have been completed (Rostovtsev et al. 1992; Ruban 2006a, 2007a), providing sufficient basis to develop a semi-quantitative approach for MFS evaluation. Further discussion of these surfaces in the global context may bring some intriguing conclusions.

\section{Geologic setting}

The evolution of the Greater Caucasus Basin began in the Sinemurian as a large back-arc basin on the northern periphery of the Neo-Tethys Ocean (Ruban 2006b) (Fig. 1). The present plate tectonic reconstructions (Stampfli and Borel 2002; Golonka 2004; Scotese 2004) suggest that a number of basins existed in the region between the stable structures of Eurasia and small terranes joined to the southern margin of this continent in the Triassic-Early Jurassic. The Greater Caucasus Basin was a relatively narrow elongated structure. Its northern part was a shelf attached to the Russian Platform, whereas the deepest central part was located in the south and stretched along the Northern Transcaucasian Arc, which, after a collision with the Southern Transcaucasian Arc in the Middle Jurassic, became the unique Transcaucasian Arc (Ruban 2006b).

The Greater Caucasus Basin was embraced by the Caucasian Sea (Ruban 2006b). In the Sinemurian-Bathonian, siliciclastic deposition dominated this basin (Fig. 1), when it was relatively deep. Deposition of shale and a lesser proportion of sand and silt prevailed. A characteristic feature is an abundance of darkcolored shale with submarine slumping patterns, deposited in deep-marine dysoxic environments in the Sinemurian-Bathonian succession. However, rare carbonate beds are also known from in this section. Carbonate and later evaporite deposition prevailed in the Callovian-Tithonian (Fig. 1), when the basin became much shallower (Rostovtsev et al. 1992; Ruban 2007a). Reefal limestone is 


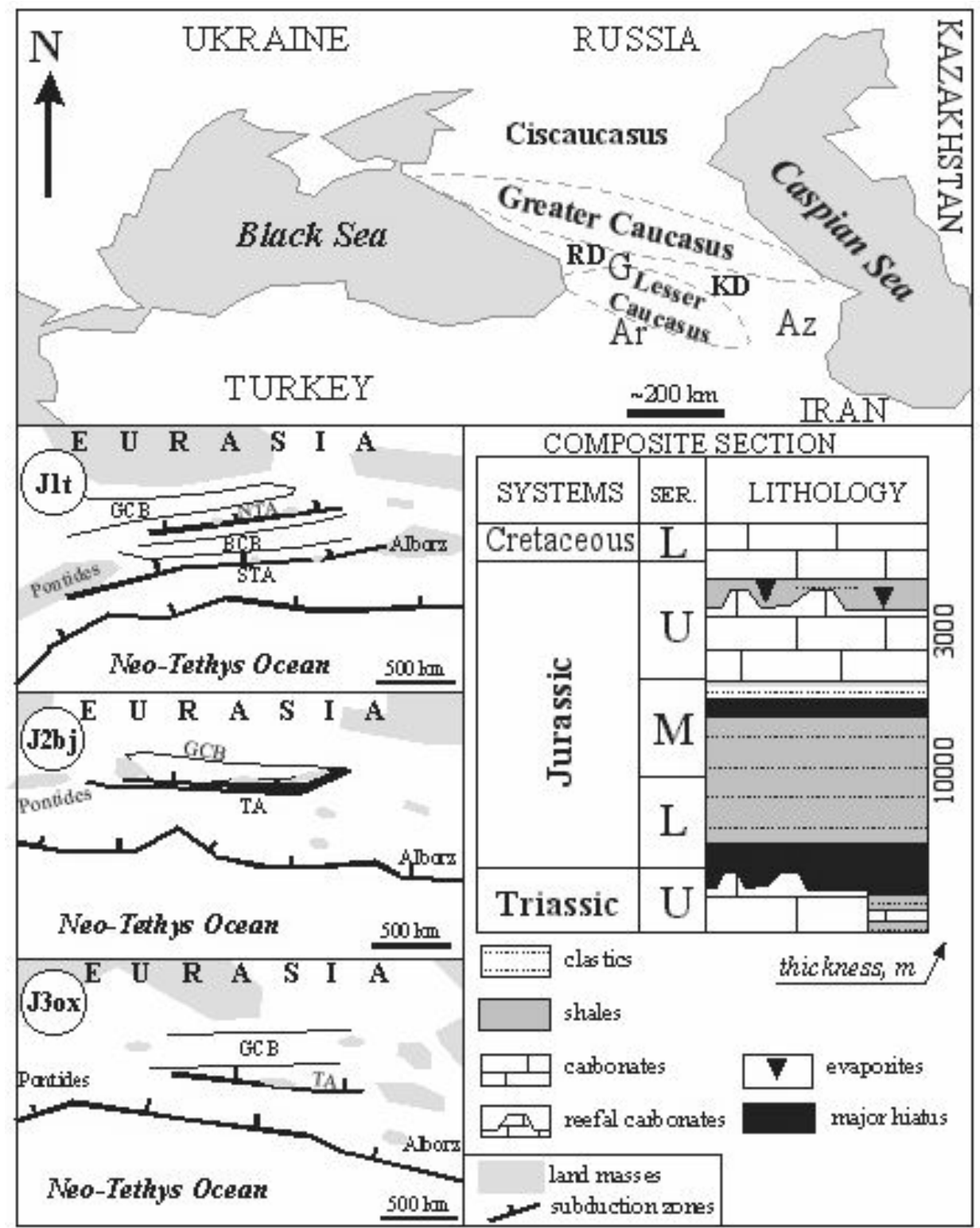

Fig. 1

Location of the Greater Caucasus Basin. Abbreviations: G - Georgia, Az - Azerbaijan, Ar - Armenia; RD - Rioni Depression, KD - Kura Depression; J1t - Toarcian, J2bj - Bajocian, J3ox - Oxfordian; GCB - Greater Caucasus Basin, BCB - Black Sea-Caspian Sea Basin, NTA - Northern Transcaucasian Arc, STA - Southern Transcaucasian Arc, TA - Transcaucasian Arc. Paleogeographic sketch maps are modified after Ruban (2006b). Composite section is after Ruban (2006c) 
abundant in some areas. During the Callovian condensed sedimentation of coarse clastics, sand, and shale occurred (Ruban 2007b). The total thickness of the Jurassic strata in the Greater Caucasus is up to $13,000 \mathrm{~m}$. Major unconformities are known from the base of the Jurassic and from the Bathonian (Ruban 2007b). They potentially indicate phases of regional tectonic activity, which resulted from the collision of the Greater Caucasus Terrane with Eurasia and the arc-arc collision, respectively (Ruban 2007b).

A number of transgressions and regressions are identified throughout Jurassic times of the Greater Caucasus (Ruban 2007a). As suggested by the present modeling (Ruban 2006b) the Greater Caucasus Basin was open to the adjacent marine basins and the Neo-Tethys Ocean, located to the south (Fig. 1). If that is correct, both eustasy and local tectonics were responsible for the regional transgressions and regressions.

\section{Material and method}

To identify the Jurassic MFSs in the Greater Caucasus Basin the data first presented by Rostovtsev et al. (1992) were used. They include detailed lithological descriptions of the Jurassic deposits supported by a precise biostratigraphic framework. The study territory is subdivided into a number of particular areas, distinguished by the differences in the Jurassic deposits and facies. These areas are established separately for the Sinemurian-Bathonian and the Callovian-Tithonian intervals (Fig. 2). Ruban (2007a) complemented, corrected, and interpreted the data by Rostovtsev et al. (1992) for each area. This was supported by biostratigraphic justification. Results from the present author's own field studies in the Western Caucasus were taken into account to make some corrections. Continental, shallow-marine, and deep-marine facies were interpreted for each area (Fig. 3) (Ruban 2007a). For the continental facies, those interpreted by hiatuses were distinguished from those interpreted by subaerial strata. The latter are very few and it does not make sense to use them for further semi-quantitative constraints.

A semi-quantitative evaluation of MFSs is based on the approach similar to that already proposed by Ruban (2007a). Several time slices were chosen. The TRn index was calculated for each of them:

$\operatorname{TR} n=(s+d) / z$,

where $s$ is the number of areas with shallow-marine facies, $d$ is the number of areas with deep-marine facies, and $z$ is the total number of areas. A calculation of TRn values for selected time slices permits the reconstruction of the regional transgression-regression curve (T-R curve). Although the size of the areas is different (Fig. 2), each of them is characterized a priori by different sedimentation (Rostovtsev et al. 1992). In other words, each area may be considered as an individual depositional sub-system. This permits assuming their equality. Moreover, it is impossible to measure the true size of these areas in the Jurassic, 

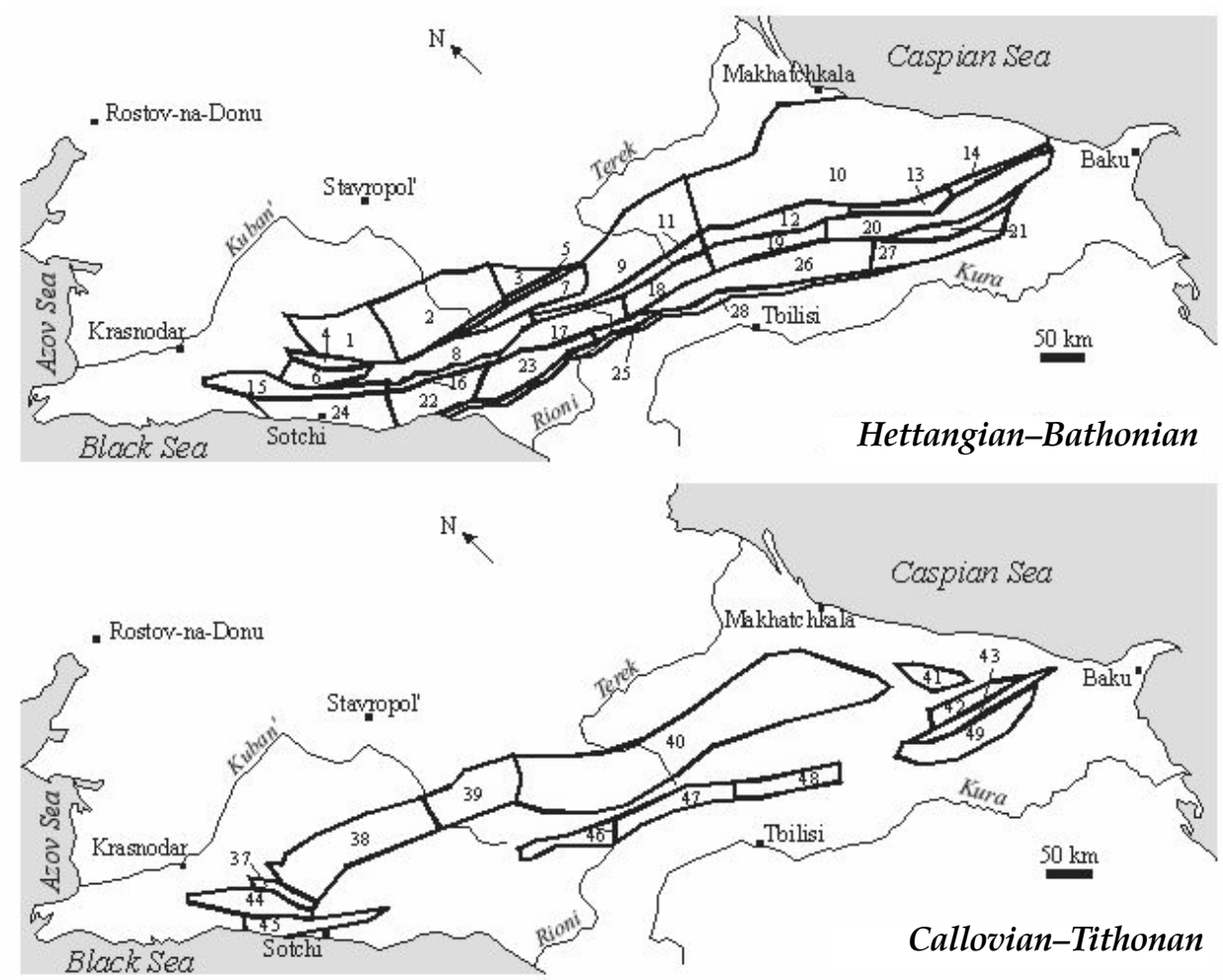

Fig. 2

Areas of the Greater Caucasus Basin (modified after Rostovtsev et al., 1992; area nomenclature and numbers after Ruban, 2007a). Omitted numbers (29-36, 50-62) belong to the other counterparts of the Caucasus

because their configuration was subsequently changed tectonically. In this study, a total of 67 time slices were prepared (Fig. 3). Five time slices were selected within each stage, and all stage boundaries were also chosen as time slices. Higher values of TRn mark an extending of the marine basin; thus, peaks on the T-R curve mark MFSs.

Any MFS marks the widest extent of the marine basin or, in other words, the most landward position of the shoreline (Bhattacharya 1993; Catuneanu 2006; Veeken 2007). If that is correct, our approach provides a valid method to emplace any concrete MFS, so no additional confirmation from the local records is required. However, it is attempted herein to briefly examine the deposits where a given MFS is established. For this purpose, special attention is paid to the LabaMalka area (northwestern part of the Greater Caucasus Basin), where the Jurassic succession is well exposed and the Toarcian-Tithonian interval was examined by the author. 


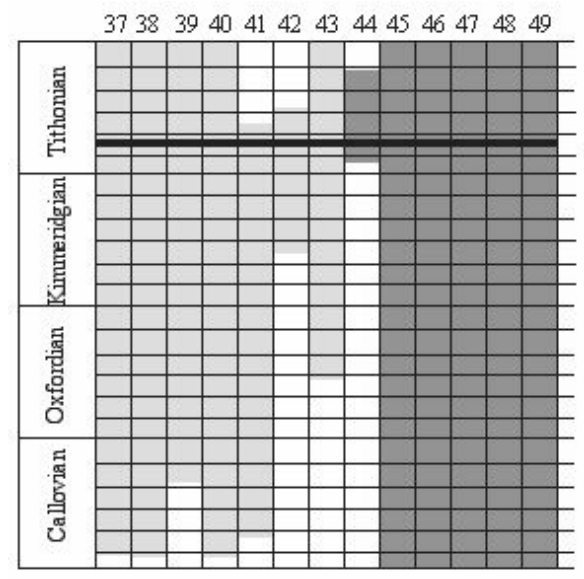

FACIES:

MFSS

$\square$ continental

(hiatuses)

continental

(subaerial dèposits)

$\square$ shallow-marine

(shelfal deposits)

$\square$ deep-marine

(slope deposits; turbidites)

? means uncertainties in the

sedimentary record, these intervals

are omitted for calculations

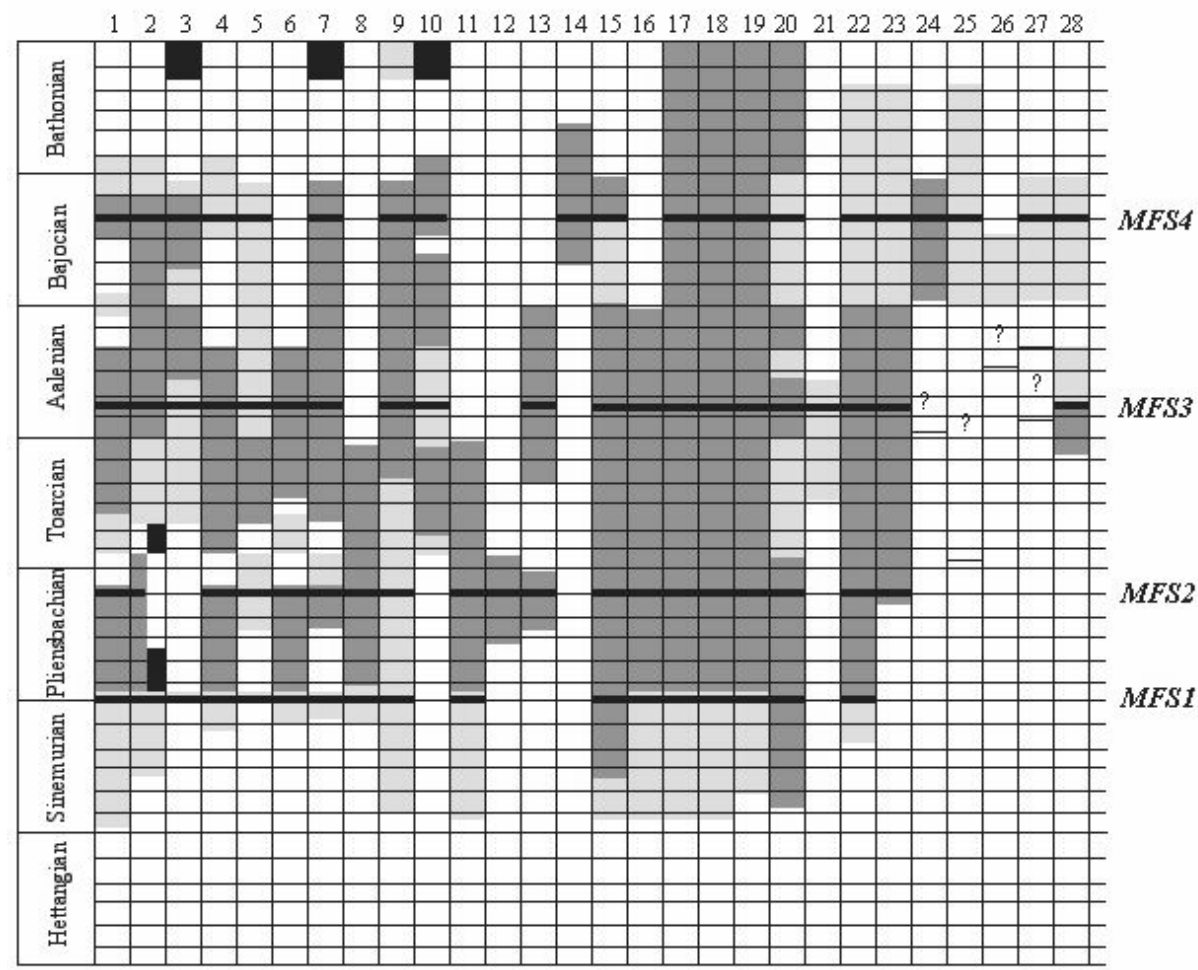

Fig. 3

Interpreted facies of the Jurassic deposits of the Greater Caucasus Basin (modified after Ruban 2007a). See Fig. 2 for area location and their true proximity (columns are placed in a random numerical order). Parallel lines indicate slices used herein for the reconstruction of the transgressive-regressive pattern. Bold lines depict MFSs interpreted in Fig. 4 


\section{Evaluation of the maximum flooding surfaces}

The regional Jurassic T-R curve of the Greater Caucasus Basin indicates a rapid fluctuation of its shoreline (Fig. 4). A repetition of transgressions and regressions took place in the Early-Middle Jurassic, whereas a stepwise transgression followed by a relatively short-term regression occurred during the Late Jurassic. Five peaks on the regional Jurassic T-R curve are also evident. They exist at the Sinemurian/Pliensbachian boundary, in the late Pliensbachian, in the early Aalenian, in the late Bajocian and in the early Tithonian. All these peaks should be interpreted as regional MFSs, which are characterized below.

MFS1 corresponds to the Sinemurian/Pliensbachian boundary, i.e. to the base of the Uptonia jamesoni Regional Zone. In the Laba-Malka area, the finingupward sedimentary succession of the Bugunzhinskaja Formation is typical for the upper Sinemurian-lowest Pliensbachian (Rostovtsev et al. 1992; Ruban 2007a). At its top dark-colored organic-rich shale with carbonate concretions and limestone lenses with siderite exist (Rostovtsev et al. 1992), which is typical for MFS-marking layers (Catuneanu 2006). MFS2 occurs within the late Pliensbachian, i.e., it corresponds to the Amaltheus margaritatus Regional Zone. In the Laba-Malka area this interval is represented by dark-colored organic-rich shale with siderite concretions of the Tchubinskaja Formation (Rostovtsev et al. 1992; Ruban 2007a), which is also typical for MFS-marking layers (Catuneanu 2006). MFS3 lies within the lower Aalenian, i.e., within the Leioceras opalinum Regional Zone. In the Laba-Malka area dark-colored shale with quite abundant siderite concretions and even pyrite grains of the Tubinskaja Formation and its lateral equivalent is typical for this interval (Rostovtsev et al. 1992; Ruban and Tyszka 2005; Ruban 2007a). The siderite concretions are abundant in the studied outcrops along the rivers Belaja, Sjug, and Gruzinka. In the central and eastern part of this area the entire Tubinskaja Formation, the age of which is middle Toarcian-middle Aalenian, represents a fining-upward sedimentary succession (Rostovtsev et al. 1992; Ruban 2007a). Dark shale dominates the entire Tubinskaja Formation in its western part. Such monotonous deposits with rare sandstone and carbonate interbeds are widespread in depressions between the Skalisty (Rocky) and the Peredovoj (Peripheral) mountain ranges. The sedimentary patterns described above coincide with the general characteristics of MFSmarking layers (Catuneanu 2006). What is surprising is the presence of a minor regressive episode just below this MFS (Fig. 4). It is known from the local record of the Laba-Malka area as an erosional surface below the upper member of the Tubinskaja Formation (Rostovtsev et al. 1992). MFS4 is traced within the upper Bajocian, i.e., it lies within the interval encompassing the Strenoceras niortense and Garantiana garantiana regional zones. In the Laba-Malka area, dark-colored organic-rich shale with siderite or fine siliciclastics of the Dzhangurskaja Formation and its lateral equivalents is known from the Bajocian. However, a transition from an interval with few layers with coarser siliciclastics to one with a significantly larger number of such layers occurs lower - somewhere in the 
106 D. A. Ruban

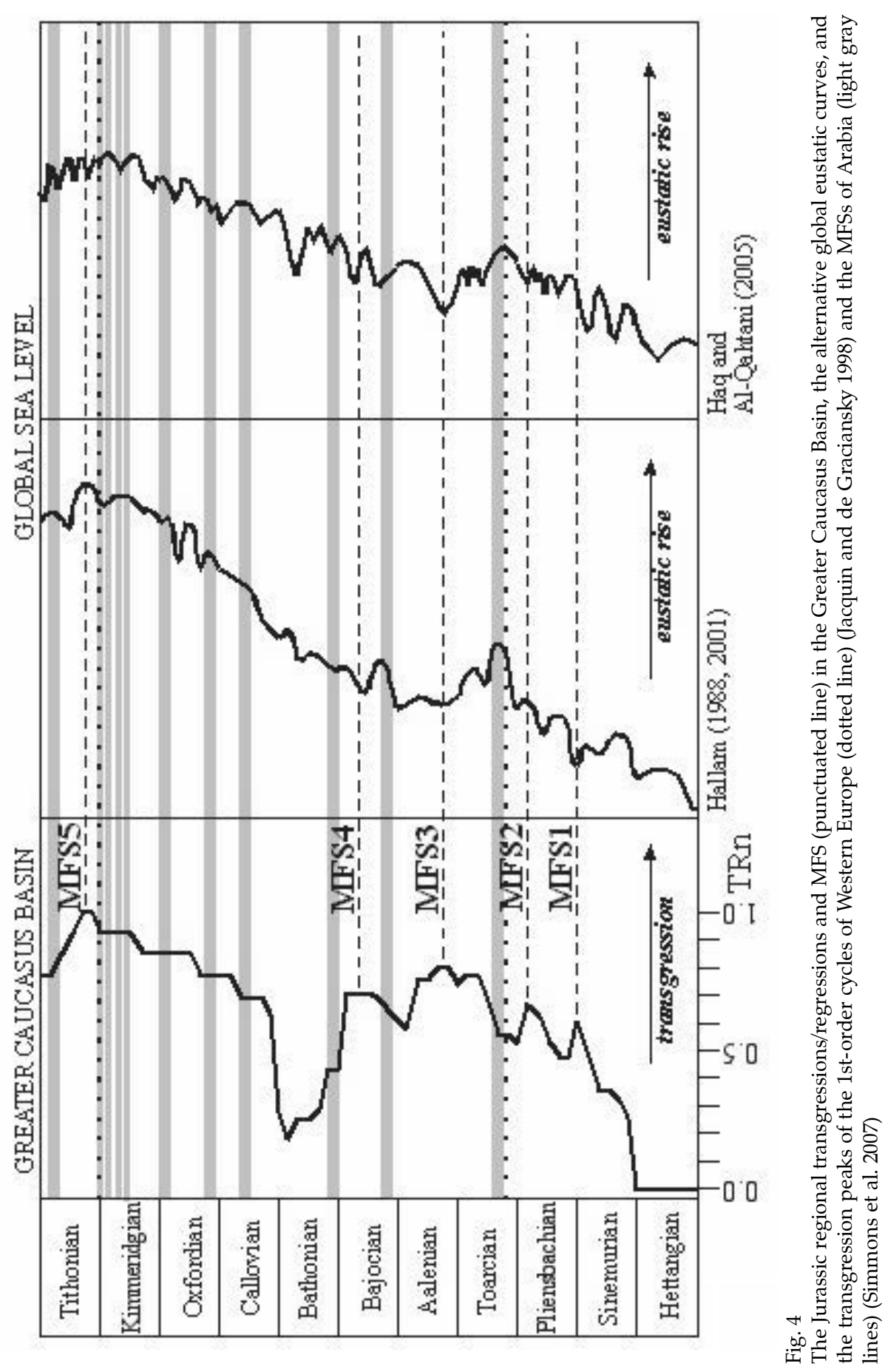

Central European Geology 51, 2008 
middle Bajocian (Rostovtsev et al. 1992; Ruban 2007a). Thus, one can expect the MFS4 within the Stephanoceras humphriesianum Regional Zone based on the existence of the MFS-marking layers. To explain this controversy it is necessary to remember that changes in basin depth, not only shifts in the shoreline, are responsible for sedimentation character. Moreover, transgressive-regressive and deepening-shallowing patterns are not directly connected, which was already demonstrated for an example of the Caucasus (Ruban 2007a). If this is so, an observed slight delay between a change from fining-upward to coarseningupward succession and the MFS4 is not so strange. The Lower-Middle Jurassic MFSs 1-4 lie within the sedimentary packages dominated by dark-colored shale with siderite. However, these deposits have a larger stratigraphic range and they should not be considered as thin marker beds. Thus only a broad correspondence may be observed. In the absence of other indicators of MFSs the latter seems to be enough to confirm their position. However, the semi-quantitative approach used in this study is itself informative and permits registering surfaces within monotonous successions, which are difficult to identify only by field observations.

MFS5 occurs within the lower Tithonian [the regional biozonation is not welldeveloped for this stage (Rostovtsev et al. 1992)]. In the Laba-Malka area this interval is dominated by siliciclastics of variegated color (the upper part of the Mezmajskaja Formation), which was generally deposited in lagoons (Rostovtsev et al. 1992; Ruban 2006a, 2007a). The presence of cross-bedding in the lower Tithonian sandstone observed by the author in the Kamennomostskij section can be considered as preliminary evidence to hypothesize an increase in fluvial energy. Abrupt shifts from meandering to braided fluvial systems are suggested by Shanley et al. (1992) and by Catuneanu (2006) as indicators of MFS in alluvial deposits. Both theoretical considerations (e.g. Catuneanu 2006) and our local evidence suggest that further field investigation is necessary. If the Upper Jurassic beds of variegated color are interpreted as continental facies, this will push MFS5 downward. However, this siliciclastic unit was not deposited in a continental environment sensu stricto. It accumulated in large lagoons (Jasamanov 1978), which are marginally marine, but not continental depositional systems (Boggs 2006). In those areas where the Mezmajskaja Fm. is present these beds are intercalated with limestone (Rostovtsev et al. 1992), suggesting not only a proximity to the shoreline, but a repetition of lagoonal and typical marine deposition. Any alternative interpretation of depositional environments of the Mezmajskaja Fm. will be fairly doubtful. However, an accumulation of the underlying evaporites of the lower part of the Mezmajskaja Fm. can be described either by lagoonal deposition along the shore or dense brine accumulation in the relatively deep basin. Proving one of these two competing models of evaporitic sedimentation (Boggs 2006; Veeken 2007) for the Greater Caucasus Basin would provide a clue to firm knowledge on the origin of MFS5. 


\section{Interregional correlation of the maximum flooding surfaces}

It is important to correlate the Jurassic MFSs of the Greater Caucasus with those established in the other regions. Western Europe and Arabia have the most accurately-established frameworks for their Jurassic stratigraphic architecture. Two transgression peaks of 1st-order transgressive-regressive cycles are established in Western Europe (Jacquin and de Graciansky 1998). One of them occurs in the early Toarcian and another is known from the KimmeridgianTithonian transition (Fig. 4). None of these matches the MFSs semi-quantitatively evaluated in the Greater Caucasus Basin. A remarkable retardation of the MFS3 in comparison to the early Toarcian transgression peak in Western Europe is noted. MFS5 lies above, but more closely to the Kimmeridgian-Tithonian transgression peak in Western Europe.

Numerous Jurassic maximum flooding surfaces are established in Arabia, although their exact position is somewhat questionable (Sharland et al. 2001; AlHusseini 2007; Simmons et al. 2007; Al-Husseini and Matthews 2008). Simmons et al. (2007) in their latest review identify MFSs in the lower Toarcian, the lower Bajocian, the lower Bathonian, the middle Callovian, the lower Oxfordian, the upper Oxfordian, the upper Kimmeridgian (four surfaces are concentrated there), and the upper Tithonian (Fig. 4). Surprisingly, despite their abundance, none of these Arabian MFSs can be correlated directly with the MFSs evaluated in the Greater Caucasus Basin.

\section{Discussion}

Two alternative global eustatic curves have been proposed for the Jurassic. The first was proposed by Hallam (1988), with slight modifications in a later publication (Hallam 2001). The second curve was proposed by Haq and AlQahtani (2005), who updated the curve proposed earlier by Haq et al. (1987, 1988). Although these curves demonstrate comparable trends in the global sealevel changes throughout the Jurassic, many differences between them exist. Previous research concluded that regional transgressions and regressions established within the Caucasus generally correspond to the global eustatic pulses (Ruban 2006a, 2007a). Also, it makes sense to compare the regional Jurassic MFSs evaluated with a greater precision in this study with the eustatic peaks (Fig. 4).

MFS1 does not have a clear analogue in the global record. Hallam $(1988,2001)$ depicts eustatic rise somewhat earlier, in the late Sinemurian, whereas Haq and Al-Qahtani (2005) indicate a significant rise a bit later, in the early Pliensbachian. MFS 2 is well reflected by Hallam's $(1988,2001)$ curve, whereas an eustatic rise is shown for slightly earlier time by Haq and Al-Qahtani (2005). The placement of MFS3 is the most controversial because it corresponds to a sharp sea-level falls suggested by both Hallam $(1988,2001)$ and Haq and Al-Qahtani (2005). MFS4 coincides with an eustatic fall on the curve by Hallam (1988, 2001), but Haq and 
Al-Qahtani (2005) indicate eustatic rise in the middle Bajocian. MFS5 is reflected by significant eustatic highstands on both global curves, although this correspondence is better established with the curve by Hallam $(1988,2001)$. Correlating the transgression peaks of the 1st-order cycles of Western Europe and the MFSs of Arabia with the global curves suggests their better correspondence. However, some differences between eustatic rises and the MFSs exist somewhere, and it is not a rule that all global sea-level highstands are reflected in the regional records (Fig. 4). It is necessary to emphasize that both key transgression peaks established in Western Europe find direct analogs among the Arabian MFSs. Moreover, they correspond to the most important highstands of the Jurassic global sea level.

It is important to note that a number of global sea-level rises documented by both Hallam $(1988,2001)$ and Haq and Al-Qahtani (2005) did not correspond with any prominent peaks of transgressions in the Greater Caucasus Basin. A typical example is the strong eustatic rise occurring in the beginning of the Toarcian. The curve reconstructed in the present study does not indicate any peak, but only an onset of a long-term transgression (Fig. 4). The field data from the western part of the Laba-Malka area permit documenting a fining-upward succession of the lower-middle Toarcian. Deposition of coarse clastics prevailed in the early Toarcian with a subsequent change to fine clastics and shale. A deposition of deep-marine strata (dark-colored shale) started just after the middle Toarcian, when a global eustatic fall began (Fig. 4).

The above-mentioned comparison of regional and global data suggest their uncertain relationships. These can be explained by errors in regional stratigraphic scales, errors in MFS evaluation and dating [see discussions by Jacquin and de Graciansky (1998) for Europe and Al-Husseini (2007) for Arabia], errors in global eustatic curves [discussed by Hallam (2001)], and a true diachroneity of the sealevel changes because of regional tectonic influences. In contrast to Western Europe, which was quite stable, and Arabia with its calm tectonic regime, the Greater Caucasus Basin was tectonically very active during the Jurassic. Thus, it is not surprising that the MFSs established there correlate so poorly with surfaces of Western Europe and Arabia and the eustatic rises. If one accepta that the possible apparent diachroneity (due to errors in constraints and interpretations) is as large as a substage, one does observe somewhat better correspondence between the regional and global transgressive patterns. A striking exception is MFS3, which marks a transgression, analogs of which cannot be found in the global or other regional records even with a noted degree of apparent diachroneity. It is also necessary to remember a significant lagging of the Toarcian events in Tibet (Hallam 2006; Wignall et al. 2006). Ruban (in press) attempted to explain this delay in both the Greater Caucasus and Tibet by a tectonic separation of the Alpine Tethys and the Neo-Tethys oceans. 


\section{Conclusions}

The semi-quantitative approach used in this study permitted the identification of five regional Jurassic maximum flooding surfaces in the Greater Caucasus Basin. They are established at the Sinemurian/Pliensbachian boundary, in the upper Pliensbachian, the lower Aalenian, the upper Bajocian, and the lower Tithonian. Deposits at the level of these surfaces are typical for MFS-defining layers, except for MFS4. The global context of the regional MFSs is generally unclear. Possible errors in constraints and interpretations and/or an intense tectonic activity complicate their correlation with key surfaces of Western Europe and Arabia as well as with the global eustatic rises. This diminishes the importance of the MFSs from the Greater Caucasus Basin as trustworthy correlation horizons. Generally, such a conclusion results in a difficulty in establishing the correspondence of sequence stratigraphic marker surfaces between tectonically active and epicontinental basins.

The present study suggests the necessity to develop comprehensive sequence stratigraphic and tectonic models for the Greater Caucasus Basin. This will provide us with a necessary clue to explain many peculiarities of its evolution. The most surprising results can be obtained from studies explaining the nature of a significant retardation of the transgression peak occurring as late as in the early Aalenian.

\section{Acknowledgements}

The author gratefully thanks G. Császár (Hungary) and A. Vörös (Hungary) for their useful suggestions, T.C. Wynn (USA) for his linguistic correction and general opinion, "CEU" Editorial Staff for a technical support, M.I. Al-Husseini (Bahrain), M. Bécaud (France), N.M.M. Janssen (Netherlands), W. Riegraf (Germany), and other colleagues for their valuable help with literature. The help by P.V. Dolmatov (Russia) during my field studies is highly appreciated. This paper is dedicated to the memory of V.I. Pugatchev (Russia), a great expert in the Caucasian geology and nature, an outstanding teacher, and an enthusiastic colleague, who always supported my field studies and gave valuable scientific instructions. His admirable sense of life became a great example for students, and his name will remain in our hearts forever.

\section{References}

Al-Husseini, M. 2007: Revised ages (Ma) and accuracy of Arabian Plate maximum flooding surfaces. - GeoArabia, 12, pp. 167-170.

Al-Husseini, M., R.K. Matthews 2008: Jurassic-Cretaceous Arabian Orbital Stratigraphy: The AROSJK Chart. - GeoArabia, 13, pp. 89-94.

Bhattacharya, J.P. 1993: The expression and interpretation of marine flooding surfaces and erosional surfaces in cores; examples from the upper Cretaceous Dunvegan Formation, Alberta Foreland basin, Canada. - In: Posamentier, H.W., C.P. Summerhayes, B.U. Haq, G.P. Allen (Eds): Sequence 
Stratigraphy and Facies Associations. International Association of Sedimentologists Special Publication, 18, pp. 125-160.

Boggs, S., Jr. 2006: Principles of Sedimentology and Stratigraphy, 4th Edition. - Pearson Prentice Hall, Upper Saddle River. 662 p.

Catuneanu, O. 2006: Principles of Sequence Stratigraphy. - Elsevier, Amsterdam, 375 p.

Galloway, W.E. 1989: Genetic stratigraphic sequences in basin analysis, I. Architecture and genesis of flooding-surface bounded depositional units. - American Association of Petroleum Geologists Bulletin, 73, pp. 125-142.

Golonka, J. 2004: Plate tectonic evolution of the southern margin of Eurasia in the Mesozoic and Cenozoic. - Tectonophysics, 381, pp. 235-273.

Hallam, A. 1988: A re-evaluation of Jurassic eustasy in the light of new data and the revised Exxon curve. - In: Wilgus, C.K., B.S. Hastings, C.G.St.C. Kendall, H.W. Posamentier, C.A. Ross, J.C. Van Wagoner (Eds): Sea-Level Changes - An Integrated Approach. Society for Economic Paleontologists and Mineralogists Special Publication, 42, pp. 261-273.

Hallam, A. 2001: A review of the broad pattern of Jurassic sea-level changes and their possible causes in the light of current knowledge. - Palaeogeography, Palaeoclimatology, Palaeoecology, 167, pp. 23-37.

Hallam, A. 2006: Facies and carbon isotope studies in southern Tibet suggest that the Toarcian extinction was diachronous. - 7th International Congress on the Jurassic System, September 6-18, 2006. Krakow, Poland. Volumina Jurassica, 4, p. 168.

Haq B.U., A.M. Al-Qahtani 2005: Phanerozoic cycles of sea-level change on the Arabian Platform. GeoArabia, 10, pp. 127-160.

Haq, B.U., J. Hardenbol, P.R. Vail 1987: Chronology of Fluctuating Sea Levels Since the Triassic. Science, 235, pp. 1156-1167.

Haq, B.U., J. Hardenbol, P.R. Vail 1988: Mesozoic and Cenozoic chronostratigraphy and cycles of sealevel change. - In: Wilgus, C.K., B.S. Hastings, C.G.St.C. Kendall, H.W. Posamentier, C.A. Ross, J.C. Van Wagoner (Eds): Sea-Level Changes - An Integrated Approach. Society for Economic Paleontologists and Mineralogists Special Publication, 42, pp. 71-108.

Jacquin, T., P.-C. de Graciansky 1998: Major transgressive/regressive cycles: the stratigraphic signature of European basin development. - In: de Graciansky, P.-Ch., J. Hardenbol, Th. Jacquin, P.R. Vail (Eds): Mesozoic and Cenozoic Sequence Stratigraphy of European Basins. Society for Economic Paleontologists and Mineralogists Special Publication, 60, pp. 15-29.

Jasamanov, N.A. 1978: Landshaftno-klimatitcheskie uslovija jury, mela i paleogena Juga SSSR [Landscape and climatic conditions of the Jurassic, the Cretaceous and the Paleogene of the South of the USSR]. - Nedra, Moskva. 224 p. (In Russian.)

Posamentier H.W., G.P. Allen 1999: Siliciclastic sequence stratigraphy: concepts and applications. Society for Economic Paleontologists and Mineralalogists Concepts in Sedimentology and Paleontology, 7, pp. 1-210.

Rostovtsev, K.O., V.B. Agaev, N.R. Azarjan, R.G. Babaev, N.V. Beznosov, T.A. Gasanov, V.I. Zesashvili, M.G. Lomize, T.A. Paitchadze, D.I. Panov, E.L. Prosorovskaya, A.S. Sakharov, V.A. Todria, M.V. Toptchishvili, M.R. Abdulkasumzade, A.S. Avanesjan, V.S. Belenkova, N.S. Bendukidze, V.Â. Vuks, M.P. Doludenko, A.I. Kiritchkova, V.G. Klikushin, G.Â. Krymgol'ts, G.M. Romanov, TV. Shevtchenko 1992: Jura Kavkaza [Jurassic of the Caucasus]. Nauka, Sankt-Peterburg. 185 pp. (In Russian.)

Ruban, D.A. 2006a: Taxonomic diversity dynamics of the Jurassic bivalves in the Caucasus: regional trends and recognition of global patterns. - Palaeogeography, Palaeoclimatology, Palaeoecology, 239, pp. 63-74.

Ruban, D.A. 2006b: The palaeogeographic outlines of the Caucasus in the Jurassic: The Caucasian Sea and the Neotethys Ocean. - Geološki anali Balkanskoga poluostrva, 67, pp. 1-11.

Ruban, D.A. 2006c: Diversity changes of the Brachiopods in the Northern Caucasus: a brief overview. - Acta Geologica Hungarica, 49, pp. 57-71. 
Ruban, D.A. 2007a: Jurassic transgressions and regressions in the Caucasus (northern Neotethys Ocean) and their influences on the marine biodiversity. - Palaeogeography, Palaeoclimatology, Palaeoecology, 251, pp. 422-436.

Ruban, D.A. 2007b: Major Paleozoic-Mesozoic unconformities in the Greater Caucasus and their tectonic re-interpretation: A synthesis. - GeoActa, 6, pp. 91-102.

Ruban, D.A. in press: The Jurassic events in the Greater Caucasus basin (central Northern Neotethys) and the Neuquén basin (West Gondwana): A comparison. - Revista de Asociación Geológica Argentina.

Ruban, D.A., J. Tyszka 2005: Diversity dynamics and mass extinctions of the Early-Middle Jurassic foraminifers: A record from the Northwestern Caucasus. - Palaeogeography, Palaeoclimatology, Palaeoecology, 222, pp. 329-343.

Scotese, C.R. 2004: A continental drift flipbook. - Journal of Geology, 112, pp. 729-741.

Sharland, P.R., R. Archer, D.M. Casey, R.B. Davies, S.H. Hall, A.P. Heward, A.D. Horbury, M.D. Simmons 2001: Arabian Plate sequence stratigraphy. - GeoArabia Special Publication, 2, pp. $1-371$.

Shanley, K.W., P.J. McCabe, R.D. Hettinger 1992: Significance of tidal influence in fluvial deposits for interpreting sequence stratigraphy. - Sedimentology, 39, pp. 905-930.

Simmons, M.D., P.R. Sharland, D.M. Casey, R.B. Davies, O.E. Sutcliffe 2007: Arabian Plate sequence stratigraphy: Potential implications for global chronostratigraphy. - GeoArabia, 12, pp. 101-130.

Stampfli, G.M., G.D. Borel 2002: A plate tectonic model for the Paleozoic and Mesozoic constrained by dynamics plate boundaries and restored synthetic oceanic isochrons. - Earth and Plantary Science Letters, 196, pp. 17-33.

Van Wagoner, J.C., H.W. Posamentier, R.M. Mitchum, P.R. Vail, J.F. Sarg, T.S. Loutit, J. Hardenbol 1988: An overview of sequence stratigraphy and key definitions. - In: Wilgus, C.K., B.S. Hastings, C.G.St.C. Kendall, H.W. Posamentier, C.A. Ross, J.C. Van Wagoner (Eds): Sea-Level Changes An Integrated Approach. Society for Economic Paleontologists and Mineralogists Special Publication, 42, pp. 39-45.

Veeken, P.C.H. 2007: Seismic Stratigraphy, Basins Analysis and Reservoir Characterisation. - Elsevier, Amsterdam. 509 p.

Wignall, P., T. Hallam, R. Newton, J. Sha 2006: Trouble in t'Toarcian of Tibet. - The Palaeontological Association. 50th, Annual Meeting, 18th-21st December, 2006, University of Sheffield, Abstracts, p. 39. 